\title{
Analysis of the Implementation of Elementary School Sport Club Management
}

\author{
Hendra Jaya Pratama \\ Master Program in Sport Sciences \\ Yogyakarta State University \\ Yogyakarta, Indonesia \\ ruliansyahb@gmail.com
}

\author{
Lismadiana \\ Faculty of Sport Sciences \\ Yogyakarta State University \\ Yogyakarta, Indonesia \\ lismadiana@uny.ac.id
}

\begin{abstract}
- this aim of the research was to analyze the implementation of elementary school sport club management in the Special Region of Yogyakarta. This research was a qualitative research. Research population consisted of elementary school club in the Special Region of Yogyakarta. Research sample was determined by the application of random sampling technique, which was derived from two elementary school sport clubs - Bintang Timur and Bima Sport. Research subjects were the club leader, second club leader, secretary, money treasurer, facility and infrastructure division, training division, competition division, and public relation. Research instruments used were observation, interview, and documentation. Data analysis method used in this research was the qualitative analysis method. Findings convey that after investigation of the management of the sport clubs - Bintang Timur and Bima Sport, their planning management, organizing, and controlling had been well conducted, but there were several aspects that should be improved due to limited certified instructor resources and lack of fund in the Bima Sport Club.
\end{abstract}

Keywords - management, sport club, elementary school

\section{INTRODUCTION}

Sport is one of the elements of national development. Government has given a special attention to the improvement of sport quality in Indonesia, either educational, recreational, and achievement sports. Generally, sport covers educational sport held in an educational environment process, recreational sport held as a part of health and fitness recover processes, and achievement sport intended as an attempt to enhance athletes' skills and potencies, uplifting national integrity and dignity [1].

Achievement sport has been included in the national development system, referring to the Law Number 3 Year 2005 on National Sport System confirming that Development and Training Processes of the achievement sport should be done and directed to gain achievements in the sport field at the regional, national, or international level. Achievement sport training process was performed by each main organization. Training was also conducted to establish sport associations, develop national and regional sport training centers, and hold gradual and sustainable competitions [2].

Development of achievement sport should be continuously done to seek, monitor, educate, and train talents based on knowledge and technology in an effective and efficient way so as to improve quality of sport organization and club in the regional or central level. The development is performed trough planned, gradual, sustainable training and development processes through the application of knowledge and technology in sports [2].

The attempts of government to improve achievements in the sport field have been performed trough early sport training programs. These attempts include the establishment of education-based training centers such as PPLP, PPLM, and Sport club elementary school. Through the Director of Kindergarten and Elementary School trainings, since $1997 / 1998$, the government has held several trainings for students with interests and talents in the field of sports. The trainings are intended to create potential athletic candidates with excellent capabilities in the field of sport. Sport trainings centered in education should be able to gather and train potential athletic candidates.

A club or organization requires good management, so that activities planned can be performed effectively and efficiently. The main concepts used in investigating performances of the management is its efficiency and effectiveness. In this report, efficiency is defined as the ability to complete a task correctly. An efficient management is the management that gets outputs (result, productiveness, performance) more than inputs (worker, material, money, machine, and time). Therefore, a good management is a management that is able to minimize the cost of resource utilization to achieve determined goals or outputs. Then, an effective management be defined to be an ability to choose effective goals to reach the intended goals. The management can choose the tasks required or the effective method needed to reach a specific goal [3].

Management is an art of managing available resources such as human, goods, money, thoughts, idea, data, information, infrastructure and other resources authorized by it. It is the responsibility of the management to apply resources optimally so as to achieve organizational goals effectively and efficiently [4]. It is the function of the management to plan, organize, direct, coordinate, and supervise all activities in an organization to achieve the organization's goal effectively and efficiently. A good management has functions that must be implemented in an organization [5].

Management is required in any organization, so that the goals and targets of such organization can be achieved. Moreover, the management functions include planning, organizing, leading, and controlling. A manager is a person 
that is responsible for the implementation of management functions to achieve an organization's success [6].

\section{METHODS}

\section{A. Research Type}

This research was descriptive-qualitative research conducted in elementary school sport clubs through the use of instruments such as observations, interviews, and documentations.

\section{B. Research Time and Location}

This research was carried out between March-May 2018 and performed in the sport club Bintang Timur of Yogyakarta and Bima Sport of Gunungkidul.

\section{Population and Sample}

Population used in this research consisted of elementary school sport clubs that had participated in the elementary school sport club trainings and competitions in the Special Region of Yogyakarta. Sample used in this research was determined by the application of random sampling technique on ten elementary school sport clubs observed in the Special Region of Yogyakarta which include the elementary school sport club in SD Ungaran, SD Kotagede 1, SD Kotagede 3, SD Solo, SD Bantul Timur, SD Kaligondang, SD Juru Gentong, SD Giripurwo, SD Panggang 1, and SD Graulan. Meanwhile, the research subject was made up of the members of elementary school sport clubs having a role in the organization structures such as the leader, second leader, secretary, money treasurer, training division, competition division, facility and infrastructure division, and public relation division.

\section{Data Collction Tehcnique and Instrument}

Data collection technique applied in this research was through the use of instruments such as observation, interview, and documentation. The researchers served as the human instruments for the research. The research focus was determined, followed by the selection of informants as the data source, the examination of the data quality, analysis of the data, interpretation of the data, and then generation of an appropriate conclusion based on the findings.

\section{E. Data Analysis Technique}

Qualitative data analysis was data analysis technique employed for the research. With the use of this technique, data analysis was carried out before visitation to the research location, during the visit, and after the visit. Analysis started since the formulation and definition of the problems, before the visition to the field, and during the articulation of findings. Data analysis was performed by gathering data, reducing data, presenting data, and drawing conclusion.

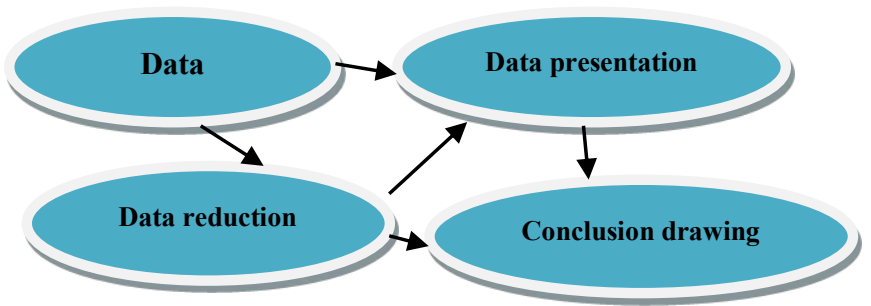

Fig. 1. Qualitative data analysis technique

\section{FINDINGS AND DISCUSSION}

\section{A. Data Analysis}

This research was conducted at the sport club Bintang Timur of Yogyakarta and Bima Sport of Gunungkidul. Data collected in this research were qualitative data gotten from observation, interview, and documentation triangulated with various research subjects.

\section{B. Discussion}

Planning is one of the fundamental functions playing very important role in an entire management, as it is a basic prose in management to decide goals and how to achieve them [5].

Planning was the initial activity carried out by both Bima Sport and Bintang Timur sport clubs in deciding their further activities and in reaching their goals. From the planning activities of Bima Sport and Bintang Timur sport clubs, shortand long-term plans, budget, training activities including trainings given by the instructors and trial trainings, competitions that would be participated in, and targets of the clubs were discussed.

Planning activities of Bima Sport club was conducted when the club started the whole activities by making plans with all members involved in the club. An organization must develop plans that would serve as the base and direction for their other future activities [7]. By performing and stipulating clear planning, the Bima Sport club had a process map to establish and attain the vision and mission of the club.

Based on these findings, we could conclude that the Bima Sport and Bintang Timur sport club had implemented good planning.

Organization has to do with the method employed in running the club, so that works become more structured and clearer. In management structures of the Bima Sport and Bintang Timur sport club, there are several divisions and each division have its own duties. For example, task division was arranged to make members aware of their duties.

Organizational structure in the Bima Sport and Bintang Timur sport clubs was made by involving all members in the local school cluster. In the Bima Sport sport club, task division was customized according to each members' competences. Organizational structure made in sport clubs involved the primary and secondary schools joined in a school cluster. After an organizational structure was made, a decision letter was made to be the principle for all other activities in accordance with its main duties and functions. Organizational structure formation is the main step needed by an organization to run itself [11].

In performing tasks given, members of theBima Sport and Bintang Timur sport clubs referred to articles of association of the club, directing the activities. Furthermore, the members were evaluated on a monthly basis and when they were found to commit mistakes, it would be discussed. Through the supervision and evaluation of members, the leader played his role actively. 
To maximize the whole activities planned, the Bima Sport club maintained a coordination among all the club members. Coordination was done every month and it became more intensely performed as O2SN competition was getting closer. In coordination, the issues found would also be discussed to find solutions. A good coordination would solve problems faced by an organization, hence smoothening the organizing activities [8].

Controlling has to do with monitoring and correcting all performance activities relating to the organizational structure. In an organization, controlling is a system systematically structured from all organizational activities to make them consistent with the expectations generated in a plan, target, and working standard. An organization is required to have a working standard that would serve as control to achieve its goals [9].

Control in the Bima Sport and Bintang Timur sport clubs aimed to supervise and evaluate all activities related to the training performed. Supervision was conducted by the sport club leader towards all members and it was carried out by observing how they have fulfilled their duties. Every month, the leaders of the Bima Sport and Bintang Timur sport clubs monitored by mentioning all members in a meeting. Supervision was done so as to investigate the progress and problems facing the club. Controlling is an important part of monitoring activities against violation that might impede the achievement of organizational goals [10].

Controlling is a process of observing the progress and barriers being faced by athletes, because the goal of sport club was to train its students' skills and competences. The results gotten from the supervision of progress and barriers of the athletes were put into a consideration when determinining the actionable steps to be taken by the clubs. If students found barriers in a certain aspect, solutions would be sought. Athletes' strengths and weaknesses were recorded and were used in guiding sport instructors.

\section{IV.CONCLUSION}

Based on the findings and analysis of the results, it was concluded that management processes in Bintang Timur and Bima Sport sport club had been run well. This is evident from the management function that had been analyzed: planning by involving all members of the Bintang Timur and Bima sport clubs. The planning also determined their goals. Then, organizing management and controlling conducted by the sport clubs were also effective. A good management of elementary school sport club and achievements of Bintang Timur and Bima Sport clubs were also the keys determining the success of the club.

\section{REFERENCES}

[1] A. Kristiyanto, Pembangunan olahraga untuk kesejahteraan rakyat \& kejayaan bangsa. Surakarta: Yuma Pustaka. 2012.

[2] Republik Indonesia. Undang-Undang RI Nomor 3, Tahun 2005, tentang Sistem Keolahragaan Nasional. 2005

[3] T. H. Handoko, Manajemen edisi 2. Yogyakarta: BPFE Yogyakarta. 2015.

[4] P. M. Yusuf, Persfektif manajemen pengetahuan informasi, komunikasi, pendidikan dan perpustakaan. Jakarta: Raja Grafindo Persada. 2012.

[5] S. Reksohadiprojo, Dasar-dasar manajemen edisi 5. Yogyakarta: BPFE Yogyakarta. 2015

[6] S. R. Robins, \& M. Coulter, Manajemen edisi kesepuluh. Erlangga. 2010 .

[7] B, Buscher, \& E. D. Beer, "The contemporary paradox of long-term planning for social-ecological change and its effect on the discoursepractice divide," evidence from southern africa, 2011. Vol 54 (3), 301318

[8] C. Osifo, Organiziation and Coordination. Finland : ISBN 978-952-476390-5, ISSN 1799-7658. 2012.

[9] T. Watts, \& C. J. Mcnair, "New performance measurement and management control system," 2012. Vol 13 (3), 226-241.

[10] T. Hernaus, A. Aleksic, M. Klinzic, Organizing for CompetitivesStruktural and Procces Charakteristic of Organiziational Design. 2013. Vol 7, 41-56.

[11] O. Dimov, \& V. Iliev, Controlling-a modern system of management and control. Vol 7 (2), 253, 2010. 